\title{
Patents, access to health and COVID-19 - the role of compulsory and government-use licensing in Ireland*
}

\author{
Aisling McMahon ${ }^{\dagger}$ \\ Maynooth University \\ Correspondence email: aisling.mcmahon@mu.ie
}

\begin{abstract}
As the race for effective vaccines and treatments for COVID-19 continues, attention must turn to how such health-technologies will be accessed globally once developed. Patents play a significant role in this context because they give the patent-holder the right to stop others using patented inventions. Patents are available on diagnostics, medicines and vaccines and could form significant access obstacles for COVID-19. Moreover, whilst many patent-holders may be willing to license health-technologies reasonably, others may not. Therefore, it is imperative that national governments ensure effective avenues exist to intervene with patent-holder discretion via compulsory licensing. This article focuses on the legal framework applicable in Ireland for such compulsory licensing interventions, interrogating the effectiveness of the current framework in alleviating access issues posed by patents for COVID-19. It demonstrates how the current framework could be reformed to make it more effective in tempering patent-holder control, where needed, whilst remaining in compliance with Ireland's international obligations.
\end{abstract}

Keywords: patents; COVID-19; compulsory licensing; governmentuse licence; service of the state; access to medicines.

\section{INTRODUCTION}

$\mathrm{T}$ he race to secure effective vaccines and treatments for COVID-19 continues at pace. ${ }^{1}$ However, as we get closer to finding effective vaccines and treatments for COVID-19, attention has turned to

* $\quad$ First published in NILQ 71.3 (2020) Autumn 331-358.

$+\quad$ Assistant Professor in Law, Maynooth University. The author would like to thank the anonymous peer reviewers for their very helpful comments. This article discusses the legal position and developments as applicable at the time of writing in September 2020.

1 Ewen Callaway, 'The race for coronavirus vaccines' (2020) 580 Nature 576; Emiliano Rodríguez Mega, 'Latin American scientists join the coronavirus vaccine race: "No one's coming to rescue us" (2020) 582 Nature 470; Ewan Callaway, 'The unequal scramble for coronavirus vaccines - by the numbers' (2020) 584 Nature 506. 
how they will be accessed once developed, by whom first and on what terms. ${ }^{2}$

In this context, intellectual property rights and particularly patents play a significant but sometimes overlooked role. ${ }^{3} \mathrm{~A}$ patent is an intellectual property right which allows the patent-holder to exclude others from using the invention under patent without the patentholder's permission (licence). This in turn means that the patent-holder can dictate many aspects of how a patented invention is provided, including, at what price and to whom. ${ }^{4}$ Where the patented invention is a health-related technology such as a vaccine, medicine or element(s) of a diagnostic, how patents are used has significant implications for healthcare because access to such technologies is often dependent on how patent-holders choose to license them. The stakes are heightened in the global pandemic context, where access to effective vaccines, medicines and diagnostics is key to saving lives and to controlling and limiting the spread of the virus. Moreover, alongside such implications for health, access to such Covid-19 health-technologies is also vital to alleviate the attendant devastation the pandemic continues to bring in terms of its effect on society and the economy more generally. ${ }^{5}$

2 These include discussions in the vaccine context around COVAX a global initiative seeking to pool vaccine procurement for COVID-19 that is co-led by the Coalition for Epidemic Preparedness Innovations, Gavi, the Vaccine Alliance, and the WHO. See discussions: 'COVAX initiative: the COVID-19 vaccine Global Access Facility' (25 August 2020); WHO, '172 countries and multiple candidate vaccines engaged in COVID-19 vaccine Global Access Facility' (News Release, 24 August 2020). See also discussions of whether there will be enough supplies of the vaccine (once developed): Roxanne Khamsi, 'If a coronavirus vaccine arrives, can the world make enough?' (2020) 580 Nature 578.

3 Other forms of intellectual property rights may also be relevant to medical technologies, discussed in part one below. In the vaccine context, the vaccine production process may often be protected by trade secret protection, and access to such trade secret information and the know-how of vaccine production can prove additional obstacles for a generic company to recreate a vaccine. See Sarah Eve Crager, 'Improving global access to new vaccines: intellectual property, technology transfer, and regulatory pathways' (2014) 104(11) American Journal of Public Health e85-e91.

4 Aisling McMahon, 'Biotechnology, health and patents as private governance tools: the good, the bad and the potential for ugly?' (2020) 18(3) Intellectual Property Quarterly 161-179.

5 In Ireland, the GDP is expected to decrease by approximately $13 \%$ in 2020 due to economic disruptions caused by the COVID-19 crisis. See Kelly C De Bruin, Eoin Monaghan, Aykut Mert Yakut, 'The environmental and economic impacts of the COVID-19 crisis on the Irish economy: an application of the I3E model' (ESRI Research Series 106, July 2020); the UN predicts that 40-60 million people globally will be pushed into extreme poverty due to economic effects of COVID-19 crisis: UN Development Programme, Brief 2: Putting the UN Framework for Socio-Economic Response to Covid-19 into Action: Insights (June 2020). 
Whilst many patent-holders have shown willingness to offer favourable licensing terms for COVID-19 health-related technologies, ${ }^{6}$ there is no legal requirement for rights-holders to do so, and others in future may not. This in turn could limit access to and supply of patented health-technologies including vaccines, medicines and diagnostics for COVID-19.

Against this backdrop it is important to consider what avenues are available to national governments to intervene with how patentholders license patented health-technologies for COVID-19 in cases where patent-holders refuse to license such technologies, or refuse to license them on reasonable terms. This article examines this issue, focusing specifically on the Irish jurisdiction as a case study and on the legal avenues for compulsory licensing and mechanisms for licensing for service of the state applicable in Ireland. ${ }^{7}$

Compulsory licensing allows states to authorise a third-party/ government to use a patented technology without the patent-holder's consent. Whilst provisions for licensing for the service of the state (socalled 'government-use provisions'), where applicable within national laws, allow the government to license a patented technology (without the patent holder's consent) for use for service of that state. Both mechanisms, where authorised, facilitate a third party/the state using a patented invention without patent-holder consent where needed and could be used where public health requires it, for example, where necessary within the COVID-19 context.

Accordingly, the article argues that it is incumbent upon the Irish government, and other national governments, to re-evaluate the current operation of such licensing mechanisms to ensure these mechanisms are as effective as possible for use within the COVID-19 context should they be required. Indeed, other jurisdictions including Germany, ${ }^{8}$ France $^{9}$ and Canada ${ }^{10}$ have already taken steps to reform or tailor existing compulsory licensing frameworks to ensure effective avenues exists to temper patent-holder control where needed for COVID-19.11 Moreover, a broader shift within the discourse is evident

6 See discussion in Aisling McMahon, 'Global equitable access to vaccines, medicines and diagnostics for Covid-19: The role of patents as private governance' (2020) Journal of Medical Ethics (forthcoming).

7 The article uses the term Ireland to describe laws applicable within the Republic of Ireland.

8 See discussion in Jennifer Enmon and Grant Shoebridge,'COVID-19 - patent rights in the time of a pandemic' (Lexology, 27 August 2020).

9 Ibid.

10 Ed Silverman, 'A Canadian bill would make it easier to issue compulsory licenses for Covid-19 products' (Stat News, 25 March 2020).

11 See general discussion of such moves in Adam Houldsworth, 'The key covid-19 compulsory licensing developments so far' (IAM, 7 April 2020). 
around how compulsory licensing provisions are being discussed in the COVID-19 context: as where previously such provisions were viewed as exceptional measures sitting at the margins of patent law discourse, COVID-19 has brought such provisions under the spotlight as viable and necessary avenues for states to use to ameliorate access issues posed by patents on COVID-19 health-technologies. Yet, there is currently a dearth of literature on the operation of such provisions generally under Irish law ${ }^{12}$ and, particularly, a notable gap on work assessing how such provisions might apply within the broader health context in Ireland, including for COVID-19.

This article fills this gap providing an overview of how these provisions operate in Ireland and offering the first comprehensive analysis of how such Irish provisions would likely apply if needed for COVID-19 including the shortcomings evident. In doing so, the article also puts forward novel reform proposals in relation to the Irish framework to make such licensing mechanisms more effective in alleviating potential access issues posed by patents on health-technologies for COVID-19 and within the health context more generally. Importantly, the article argues that current provisions within Irish law could in theory be interpreted as allowing the grant of compulsory licences or governmentuse licences in the COVID-19 context in some circumstances, but that shortcomings remain within the current framework. The amendments suggested to the domestic legal framework are aimed at increasing the effectiveness of the system, both in: 1) expanding/clarifying the scope for the use of such provisions for COVID-19; and 2) explicitly acknowledging within the legislation that such provisions can be used within the public health context thereby encouraging the use of such provisions where needed in Ireland.

Notably, alongside national laws, Ireland has obligations under EU law and international laws applicable in the compulsory licensing context. This article provides an overview of how these differing levels of obligations apply to Ireland's domestic framework, and the extent of

12 For a discussion of such mechanisms generally, see Robert Clark, Shane Smyth and Niamh Hall, Intellectual Property Law in Ireland (4th edn, Roundhall 2016) chapter 8, 'Voluntary and compulsory licenses'; European Patent Academy, 'Compulsory licensing in Europe: a country-by-country overview' (European Patent Office 2018), 61-63. For a brief discussion of the potential application of compulsory licenses for COVID-19 in Ireland, see Sophie Delaney, 'Compulsory licences on the horizon for drugs and equipment?' (William Fry, 27 March 2020); Donal M Kelly, 'COVID-19: the impact on IP law and practice in Ireland' (IP Stars, 5 May 2020); Samantha Silver and Lindsay MacLean, 'COVID-19: vaccine development and compulsory licensing' (Kennedys Law, 14 May 2020); Aisling McMahon, 'How patents will affect pandemic vaccines and treatments' (RTE Brainstorm, 3 July 2020). 
reforms possible in this context, if Ireland is to remain compliant with such international legal obligations. ${ }^{13}$

Moreover, although the arguments focus on the Republic of Ireland, such arguments have broader significance given that the obligations imposed by the Agreement on Trade-Related Aspects of Intellectual Property Rights 1995 (TRIPS Agreement) apply in all World Trade Organization (WTO) contracting states including EU states and the EU in its own right, given that the EU is a signatory to the TRIPS Agreement. ${ }^{14}$ The UK is also a signatory of the TRIPS Agreement and has participated in other WTO instruments, including the Amendment to the TRIPS Agreement in 2005,15 by virtue of the EU's signing such agreements which bound all EU states (including the UK) at the time of signature. The UK has signalled its intent to remain party to such arrangements/agreements post-Brexit. ${ }^{16}$ Accordingly, the WTO legal framework discussed in this article, which defines the parameters within which Ireland can reform its laws and remain compliant with its international law obligations, is applicable in all other WTO states including all EU states and the UK. Thus, this discussion is of broader relevance to any WTO state contemplating reform of its compulsory licensing laws in a manner which remains in compliance with WTO obligations. The obstacles posed by EU law to compulsory licensing use are also of relevance to all current EU states.

Furthermore, the legislative framework applicable in Ireland for compulsory licensing is broadly similar to the framework applicable within the UK under its Patents Act 1977, as amended, as many of the provisions applicable under Irish law were originally drawn from UK

13 Failing to comply with such international obligations under the Agreement on Trade Related Aspects of Intellectual Property Law (TRIPS Agreement) could render Ireland liable to the WTO dispute settlement mechanism and the possibility of trade sanctions for non-compliance. See general discussion on TRIPS Compliance in Edward Lee, 'Measuring TRIPS compliance and defiance: the WTO Compliance Scorecard' 18 (2011) Journal of Intellectual Property Law 401. Moreover, as the EU has signed the TRIPS Agreement, the Agreement has legal effects within the EU legal order, see Justine Pila and Paul Torremans, European Intellectual Property Law (Oxford University Press 2016) 35 and 61.

14 The EU signed the TRIPS Agreement on behalf of EU states as it was deemed to be within the competence of the EU: see Council Decision (of 22 December 1994) concerning the conclusion on behalf of the European Community, as regards matters within its competence, of the agreements reached in the Uruguay Round multilateral negotiations (1986-1994); OJ L 336 of 23/12/1994, page 1.

$15 \mathrm{WT} / \mathrm{L} / 641$, Amendment of the TRIPS Agreement (8 December 2005).

16 The UK has indicated that during the Brexit transition period it will continue to be treated as a member state of the EU for the purpose of such instruments, and after this transition period the UK has confirmed its continued acceptance of such agreements/arrangements, see 'The United Kingdom's withdrawal from the European Union - Communication from the UK' WT/GC/206 para 2.6. 
law. ${ }^{17}$ Moreover, both jurisdictions have licensing for government/ crown-use provisions - services of the state (in Ireland) and for the crown (under UK law)18 - which are similar in nature. Hence, the analysis of the domestic framework applicable in Ireland for compulsory licensing and, particularly, licensing for services of the state resonates with the framework applicable in the UK context. ${ }^{19}$

The article is structured as follows: part one examines the potential impacts patents have on access to healthcare, providing a case for why effective compulsory licensing measures are needed at the national level to alleviate access issues posed by patents in the health context. Part two then examines the overarching international framework for compulsory licensing applicable in all WTO states including Ireland. This WTO framework sets down minimum criteria which present restrictions on uses of compulsory licences at a national level for COVID-19 which Ireland must continue to abide by in any reform of national laws in this area or face the possibility of WTO dispute settlement proceedings and potential trade sanctions. Following this, part three considers the domestic compulsory licensing framework applicable in Ireland, offering a critique of how the current framework would apply to the COVID-19 context, including the shortcomings evident. It then offers proposals for how this framework could be reformed to facilitate a more effective compulsory licensing system whilst remaining compliant with Ireland's international obligations. Part four examines licensing for service of the state provisions under Irish law, focusing on their potential to be used in the COVID-19 context, and reforms which would make this system more effective. Part five then outlines practical obstacles for the use of compulsory licences in Ireland posed by EU laws around data/marketing exclusivity and the EU's opt-out of the relevant WTO framework under Article 31 bis. This section argues that such issues need to be addressed to ensure they do not cause undue barriers to compulsory licensing within EU states. Finally, part six concludes by arguing that compulsory licensing and government-use provisions are important tools within a state's broader arsenal of devices to alleviate access issues posed by patents on health-related technologies, including within the COVID-19 context. Accordingly, it is vital that national laws facilitate effective systems for such licensing interventions. The Irish state should address existing

17 Compulsory licensing is legislated for in the UK under sections 48, 48A and 48B of the Patents Act 1977 (as amended).

18 See section 55, 56 and 59 Patents Act 1977, as amended in the UK context.

19 It is, however, acknowledged that the two jurisdictions differ on some aspects, and this must be borne in mind in drawing any comparative lessons from the analysis for the UK context. 
shortcomings as soon as possible lest such licensing measures be required for COVID-19.

\section{PATENTS, ACCESS TO HEALTH AND COVID-19: THE NEED FOR EFFECTIVE NATIONAL COMPULSORY LICENSING MECHANISMS}

Patents and patent-holder decisions on licensing can have a significant impact on access to health-technologies. ${ }^{20}$ Once a technology is patented the patent-holder has the discretion to dictate how that invention is used and by whom for the duration of the patent (generally 20 years). 21 The patent-holder can refuse to license a technology to third-parties, which could effectively mean the patent-holder becomes the sole provider of that technology and, depending on their manufacturing capacity, this can have knock-on implications for the supply of that technology. This in turn can have significant adverse implications for health if the underlying patented technology is a medicine, vaccine, or diagnostic and if supply of such technologies is limited. These issues have been brought into the spotlight by COVID-19, particularly in light of recent debates around vaccine/medicine nationalism, ${ }^{22}$ where some states have sought to negotiate agreements for preferential access of proposed vaccines or treatments for COVID-19 in their national states, ${ }^{23}$ prioritising national interests over the interests/needs of other states. Such deals can have knock-on effects causing shortages of supplies of such vaccines, medicines or diagnostics available in other states. ${ }^{24}$ Moreover, these types of deals are only likely to increase as we get closer to finding effective vaccines/treatments for COVID-19,

20 For a general discussion of the potential impacts of patents on access to and delivery of healthcare, which argues in favour of greater oversight of patentholder's discretion in this context, see McMahon (n 4).

21 TRIPS Agreement, Article 33 which states that: 'The term of protection available shall not end before the expiration of a period of twenty years counted from the filing date.'

22 See discussion in McMahon (n 6).

23 Stephen Buranyi, "Vaccine nationalism" stands in the way of an end to the Covid-19 crisis' The Guardian (London, 14 August 2020); Donato Paolo Mancini and Michael Peel , “Vaccine nationalism” delays WHO's struggling Covax scheme' Financial Times (London, 2 September 2020).

24 Sarah Boseley, 'US secures world stock of key Covid-19 drug remdesivir' The Guardian (London, 30 June 2020); Barbara Mintzes and Ellen 't Hoen, 'The US has bought most of the world's remdesivir. Here's what it means for the rest of us' (The Conversation, 3 July 2020). Similar attempts to acquire preferential supplies at a national level are evident around proposed COVID-19 vaccines. See Duncan Matthews, 'Coronavirus: how countries aim to get the vaccine first by cutting opaque supply deal' (The Conversation, 27 July 2020). 
with particularly acute effects on poorer nations and vulnerable populations. ${ }^{25}$

To alleviate these issues, states can try to encourage patentholders to share intellectual property rights via voluntary licensing initiatives as part of a broader global solidarity approach to tackle COVID-19. Notable examples of such initiatives within the COVID-19 context include the Open COVID-19 pledge, and the World Health Organization's (WHO) COVID Technology Access Pool (CTAP). ${ }^{26}$ It is undoubtedly important for states to endorse such initiatives, ${ }^{27}$ and this article is not arguing that compulsory licensing offers a substitute to replace voluntary licensing initiatives. Rather, it argues that such voluntary mechanisms to encourage sharing of intellectual property should be strongly supported and endorsed by states, as state support for such voluntary licensing initiatives can form an important nudge to encourage patent-holders to participate in such initiatives, and the more national states do so, the greater the pressure placed on patentholders to commit to voluntary licensing initiatives for COVID-19.

However, voluntary licensing models do not replace the need to have effective compulsory licensing mechanisms because voluntary licensing initiatives by their nature are subject to patent-holder opt-in, and, whilst many patent-holders may be willing to engage with these initiatives for COVID-19, they are not generally legally mandated to do so, and some patent-holders inevitably will not. Similarly, whilst many patent-holders may of their own accord be agreeable to license their COVID-19 technology on favourable terms, others may not. Accordingly, it is vital that states have an effective avenue to allow third parties or governments to use patented health-technologies without patent-holder consent where this is needed to alleviate access issues for COVID-19. Compulsory licensing and licensing for service of the state mechanisms provide such avenues, allowing states to intervene with a patent-holder's control over patented health-technologies where patent-holders refuse to license or provide such technologies

25 See also discussion on potential impacts on vulnerable populations in Ana Santos Rutschman, 'How "vaccine nationalism" could block vulnerable populations' access to COVID-19 vaccines' (The Conversation, 17 June 2020).

26 See COVID Pledge. For information on CTAP, see COVID-19 Technology Access Pool. An overview of both initiatives is provided in McMahon (n 6). See discussion of distinction between pools and pledges in: J L Contreras, M Eisen, A Ganz et al, 'Pledging intellectual property for COVID-19' (2020) 38 Nature Biotechnology 1146, 1147.

27 The benefits of voluntary licensing initiatives in such contexts, and the need for state support of these are discussed in detail in McMahon (n 6). 
on reasonable terms. ${ }^{28}$ Accordingly, where state support for voluntary licensing initiatives perform a useful 'carrot' function encouraging patent-holders to share intellectual property rights on reasonable terms, compulsory licensing is a vital 'stick' that states can use as a threat or as an mandatory measure where patent-holders do not offer reasonable terms and where public health requires access to patented technologies. ${ }^{29}$ In effect, arguably, voluntary and compulsory licensing measures are complementary in nature and serve different functions in the access to medicines context.

Put simply, compulsory licensing measures are useful in such contexts because if a patent-holder refuses to license the patented technology on reasonable terms, depending on the national patent laws applicable, a compulsory licence could be applied for in that state which, if granted, would allow the government/third-party to produce that health-technology for supply within that state. ${ }^{30}$ Alternatively, provisions allowing licences for service of the state where applicable (such as within Ireland) could be used to authorise the government to produce such technologies for that state. Such mechanisms, as noted, are useful negotiation tools, as the threat by the state of issuing a compulsory licence if reasonable licensing terms cannot be reached can be sufficient to encourage patent-holders to adopt more favourable licensing terms. ${ }^{31}$ Hence, such licensing mechanisms provide a useful avenue to alleviate access issues where public health needs require these, ${ }^{32}$ resetting the balance of control over how a patented technology is licensed away from patent-holders to states where needed. Accordingly, it is vital that existing national mechanisms

28 Such mechanisms could also be used in cases of vaccine/treatment nationalism to alleviate shortages of medicines which may arise elsewhere if patent-holders provide preferential supplies of patented vaccines, treatments, or diagnostics for particular states. See Mintzes and 't Hoen (n 24).

29 For a discussion of such measures as 'carrots and sticks' and the broader corporate responsibility context of patents, see Aisling McMahon and Edana Richardson, 'Patents, health and corporate responsibility' (Working Paper 2020) (on file with the author).

30 The issues may be more complex in the vaccine context as, alongside compulsory licences, other information on the process may be needed to allow a third party sufficient knowledge to produce the vaccine. Nonetheless, compulsory licences can help alleviate at least part of the issue posed in such contexts.

31 See discussion in Gorik Ooms and Johanna Hanefeld, 'Threat of compulsory licences could increase access to essential medicines' (2019) 365 British Medical Journal 12098.

32 See also discussion of role and use of such compulsory licensing flexibilities in Ellen 't Hoen, Jacquelyn D Veraldi, Brigit Toebes and Hans Hogerzeil, 'Medicine procurement and the use of flexibilities in the Agreement on Trade-Related Aspects of Intellectual Property Rights 2001-2016' (2018) 96 Bulletin of the World Health Organization 185-193. 
for licensing without patent-holder authorisation are examined and reformed as necessary to ensure they are as effective as possible to meet public health needs.

It is acknowledged that compulsory licensing measures are conducted at the national level, and, where such licences are granted, they are predominantly aimed at alleviating issues in the national state. Thus, some may question whether using such mechanisms is akin to vaccine/medicine nationalism by another means. However, two points can be made to this potential critique: 1) Compulsory licences issued at the national level can give rise to a momentum for change which has global benefits, causing patent-holders to voluntarily license patented technologies for use elsewhere or to commit to not enforcing their intellectual property rights - we have already seen this in the COVID-19 context for the drug Kaletra, discussed below. 2) Arguably, the greater the number of states that use compulsory licences, the more normalised compulsory licensing becomes within the patent system for public health emergency contexts such as pandemics. This can make it easier for other states to use such mechanisms, and, relatedly, the greater number of states that threaten to use compulsory licensing within a particular context, the higher the likelihood of reputational damage to patent-holders who refuse to voluntarily license their patents on reasonable terms, which again can act as a strategy to encourage effective global change. Therefore, although such compulsory measures take place at the national level, they can have much broader, global or regional benefits.

Importantly, in making such arguments, the article is not suggesting that compulsory licensing or licensing for service of the state mechanisms are a panacea to address all access issues posed by intellectual property rights within the COVID-19 context. It is conceded that patents are not the only form of intellectual property rights relevant in the COVID-19 healthcare context, and particularly within the vaccine space, where trade-secret protection is also important. ${ }^{33}$ In many cases, how a vaccine is produced may be protected by tradesecret protection and this knowledge may be necessary to create a generic version of a vaccine. This in turn differentiates vaccines from small-molecule medicines which are often easier to replicate by others without additional knowledge, e.g. of the manufacturing process, from

33 Trade secrets are defined by the World Intellectual Property Office as intellectual property rights on confidential information which may be sold or licensed'. See 'What is a trade secret?'. See also discussion in David S Levine, 'Covid-19 should spark a re-examination of trade secrets’ stranglehold on information' (Stat News, 10 July 2020). 
the patent-holder. ${ }^{34}$ In the vaccine context or for biological (complex) medicines, having a compulsory licence over the patent will not necessarily on its own enable a third party to produce a similar version of that vaccine/medicine without the third party also having access to the information protected under the trade secret or additional knowhow. This information may not be disclosed by the patent-holder, thereby requiring the third party to develop this knowledge to produce a generic vaccine - and this may be difficult and/or take considerable time. Nonetheless, this is not a reason to dismiss the role of compulsory licensing, as, even if it is more difficult to replicate a vaccine/medicine in such contexts, removing the patent obstacle will bring a third party closer to doing so. Furthermore, although outside the scope of this article, such issues arguably merely support the argument that, once a compulsory licence is issued on a patented invention, patent-holders should also disclose related information around the working of that invention, such as additional know-how and trade secret information. 35

It is also acknowledged that alongside ensuring effective measures for compulsory licensing, there is a broader issue around states' willingness to use such compulsory licensing measures in the COVID-19 context and for public health more generally. Historically, higher-income states have been reluctant to use such compulsory licensing measures given the potential threat of backlash within the international community. Indeed, countries such as Thailand, Brazil and India faced backlash from the US and elsewhere, including threats of trade sanctions, for using such measures. ${ }^{36}$ Some states, such as Ireland, with strong pharmaceutical industries may be particularly

34 Sara Eve Crager, 'Improving global access to new vaccines: intellectual property, technology transfer, and regulatory pathways' (2014) 104 American Journal of Public Health S414-S420. For a discussion on the difference between small molecule and biologic medicines and why manufacturing process information is information, see Generics and Biosimilars Initiative.

35 See discussion of possible avenues to obtain access to trade secret protected information under TRIPS in David S Levine, 'Covid-19 trade secrets and information access: an overview' (Infojustice, 10 July 2020). See also discussion in McMahon (n 6).

36 See C T Scopel and G C Chaves, 'Initiatives to challenge patent barriers and their relationship with the price of medicines procured by the Brazilian Unified National Health System' (2016) 32 Cad Saude Publica 121; S Tantivess, N Kessomboon and C Laongbua, 'Introducing government use of patents on essential medicines in Thailand, 2006-2007: policy analysis with key lessons learned and recommendations' (International Health Policy Program 2008); Z Siddiqiu, 'India defends right to issue drug "compulsory licenses"' (Reuters, 23 March 2016), as cited in E 't Hoen et al, 'Medicine procurement and the use of flexibilities in the Agreement on Trade-Related Aspects of Intellectual Property Rights, 2001-2016' (2018) 95 Bulletin of the World Health Organization 185, 189. 
reluctant to use compulsory licensing measures, fearing industry backlash. However, it is in all our interests to eradicate the virus as soon as possible, from both a health and an economic industry perspective, and this can only be achieved by ensuring effective access to COVID-19 health-technologies.

Furthermore, arguably, COVID-19 is acting as a catalyst for change in this context, as a trend towards greater acceptability of the use, and need for, effective licensing interventions in the pandemic context is evident. For example, as noted, many countries have already amended laws to ensure effective avenues to obtain compulsory licences are available where needed for COVID-19.37 Moreover, Israel issued the first compulsory licence for the pandemic on 18 March 2020, to allow it to import generic versions of AbbVie's Kaletra for COVID-19,38 rather than receiving backlash/criticism, soon after Israel issued this compulsory licence, AbbVie committed to not enforcing its patents over Kaletra globally for COVID-19.39 Given this backdrop, states, including Ireland, should be encouraged to evaluate existing systems and, arguably, will be more willing and empowered to introduce reforms and use compulsory licensing where needed for COVID-19.

Thus, in short, whilst compulsory licensing measures are not a panacea to solve all issues around access to health-technologies posed by intellectual property rights for COVID-19, they are a vital tool to alleviate access issues posed by patents. It is therefore imperative that states ensure such compulsory mechanisms are as effective as possible at a national level, so that they are open to states to use where needed to address one part of the broader access puzzle.

\section{LICENSING WITHOUT PATENT-HOLDER'S AUTHORISATION: IRELAND'S INTERNATIONAL OBLIGATIONS}

Turning then to the international framework within which licences without patent-holder's authorisation (such as compulsory licences and licences for service of the state) can be granted. At an international level, the minimum criteria for the grant of such licences are set out under Article 31 of the TRIPS Agreement. The TRIPS Agreement is applicable in all 164 WTO states globally, including Ireland. The EU is also a signatory of the TRIPS Agreement, which makes the TRIPS

37 Houldsworth (n 11); see discussion in Hilary Wong, 'The case for compulsory licensing during COVID-19' (2020) 10(1) Journal of Global Health 010358.

38 Houldsworth (n 11).

39 Phil Taylor, 'AbbVie won't enforce patents for COVID-19 drug candidate Kaletra' (PharmaForum, 25 March 2020). 
Agreement 'binding upon the institutions of the Union and its Member States'.40 Moreover, whilst the TRIPS Agreement does not have direct effect in EU member states by virtue of EU law, 41 nonetheless, when domestic courts are interpreting provisions of the TRIPS Agreement, they must do so 'as far as possible' 'in the light of the wording and the purpose' of the TRIPS provision, given the EU entered into the TRIPS Agreement on behalf of states. ${ }^{42}$ Alongside the provisions within the TRIPS Agreement, all contracting parties of the TRIPS Agreement must also comply with the substantive provisions of the Paris Convention for the Protection of Industrial Property 1883, as amended (hereafter the Paris Convention) of which Article 5 relates to licensing without the rights-holder's authorisation. 43 Thus, the TRIPS Agreement and Paris Convention set out minimum standards for the use of compulsory licences within WTO states. Moreover, because the EU is a signatory of the TRIPS Agreement, there is an additional legal impetus arising from EU law for EU member states to abide by the provisions within TRIPS.

However, patent law is jurisdictional in nature and there is no global patent system per se. Instead, in practice, a compulsory licence is obtained at the national level, and the processes to apply for compulsory licences are governed by national laws separately in each state. Therefore, whilst every WTO member state must abide by relevant provisions within the TRIPS Agreement and the Paris Convention which set down minimum standards, they are free to impose higher standards than required under these international treaties within national laws for mechanisms for licensing without patent-holder's authorisation. Differences can therefore arise in the applicable rules around compulsory licensing in each national context. Accordingly, it is only by considering the requirements under the Paris Convention, the TRIPS Agreement and under national laws in the state concerned that a picture of how such licensing mechanisms operate in each national context, such as in Ireland, can be gleaned.

This section considers the international framework applicable for the grant of licences without patent-holder authorisation, focusing specifically on the minimum criteria set out under the Paris Convention, and under the TRIPS Agreement. It identifies the main shortcomings with this international law framework in terms of how

40 Article 216(2) Treaty on the Functioning of the EU, as discussed in Justine Pila and Paul Torremans, European Intellectual Property Law (Oxford University Press 2017) 69.

41 Pila and Torremans (n 40) 69.

42 Joined Cases C-300/98 and 392/92 Parfums Christian Dior SA $v$ TUK Consultancy $B V$ [2000] I-11307 [47] as discussed ibid.

43 Many WTO states, including Ireland, were already party to the Paris Convention upon the adoption of the TRIPS Agreement in 1995. The Paris Convention came into force in Ireland on 4 December 1925. 
such international laws might impact the use of compulsory licensing mechanisms in Contracting States such as Ireland within the COVID-19 context. However, such restrictions are in many cases presented as offering a balance between patent-holders' right to intellectual property and broader public interests concerns. ${ }^{44}$ Furthermore, changes to this international framework are likely to be a longer-term project given the complexity of achieving change of the TRIPS framework. ${ }^{45}$ Within the COVID-19 context, therefore, it is more fruitful for the Irish government in the shorter term to ensure the legal framework in Ireland offers the most effective national framework for compulsory licensing possible, whilst remaining compliant with the current TRIPS framework. This national framework is discussed in part three below.

\subsection{Compulsory licensing and the Paris Convention 1883}

The Paris Convention was signed in 1883, however, the original Convention did not refer to compulsory licensing of patents. Compulsory licensing was discussed in the 1925 Revision Conference and subsequently provisions were included in the Paris Convention setting out minimum requirements for the grant of such licences. 46 In its current version, Article 5 of the Paris Convention states that contracting states of the Convention: 'shall have the right to take legislative measures providing for the grant of compulsory licences to prevent the abuses which might result from the exercise of the exclusive rights conferred by the patent, for example, failure to work'. ${ }^{47}$ This provision marks a recognition that contracting states are permitted to grant compulsory licences under the Convention. The Convention does not provide an exhaustive list of grounds under which a compulsory licence can be granted, merely providing 'failure to work' an invention as one example of a ground that a compulsory licence could be granted

44 On the right to intellectual property within the European Convention on Human Rights system, see Christophe Geiger and Elena Izyumenko, 'Intellectual property before the European Court of Human Rights' in Christophe Geiger, Craig A Nard and Xavier Seuba (eds), Intellectual Property and the Judiciary EIPIN series vol 4 (Edward Elgar 2018) 9-90. One could question the extent to which this balance incorporates other human rights concerns, such as the right to health. See, generally, discussion in Laurence R Helfer, 'Human rights and intellectual property: conflict or coexistence?’ (2003) 5 Minnesota Intellectual Property Review 47; Philippe Cullet, 'Human rights and intellectual property protection in the TRIPS Era' (2007) 29(2) Human Rights Quarterly 403-430.

45 Frederick M Abbott, 'The future of the multilateral trading system in the context of TRIPS' (1997) 20 Hastings International and Comparative Law Review 661, 667.

46 Esther Van Zimmeren and Geertrui Van Overwalle, 'A paper tiger? Compulsory license regimes for public health in Europe' (2011) 42 International Review of Intellectual Property and Competition Law 1.

47 Article 5(A)(2) Paris Convention 1883, as amended. 
for. However, it is permissible under the Paris Convention for states to adopt other grounds for compulsory licences beyond failure to work. 48 This provides considerable discretion to states in relation to the grounds which can be adopted at a national level for compulsory licensing.

Notably, the Paris Convention provides that a compulsory licence cannot be applied for:

on the ground of failure to work or insufficient working before the expiration of a period of four years from the date of filing of the patent application or three years from the date of the grant of the patent, whichever period expires last; it shall be refused if the patentee justifies his inaction by legitimate reasons ... ${ }^{49}$ (emphasis added)

This provision means that national states are restricted in providing a compulsory licence where it is granted on the ground of 'failure to work or insufficient working' until a period of three years after grant or four years from the date of application has passed. However, this time restriction is not applicable beyond the circumstance of where a licence is granted for failure to work/insufficient working, i.e. it does not apply if compulsory licences are granted on other grounds. This point is returned to below in discussing the national requirements applicable under Irish law for the grant of a compulsory licence.

\subsection{Compulsory licensing and the TRIPS Agreement}

Alongside these provisions within the Paris Convention, there are seven main cumulative requirements for a compulsory licence under the TRIPS Agreement relevant to the healthcare context and to COVID-19.50 Each of these criteria are considered here, alongside the implications of these criteria for the use of compulsory licensing for patented health-technologies for COVID-19.

Firstly, under the TRIPS Agreement, each authorisation of a compulsory licence must be considered 'on its individual merits'. ${ }^{51}$ This implies that a state, for instance, cannot issue a blanket compulsory licence for an area of technology or specific issue such as issuing a compulsory licence for all 'COVID-19 related medicines'. Instead, each application for use of a patent without the patent-holder's permission must be considered individually for each individual medicine, vaccine etc. This requirement rules out the ability of any WTO state, including Ireland, using compulsory licences in a blanket manner to facilitate access to COVID-19 health-technologies.

48 Van Zimmeren and Van Overwalle (n 46).

49 Article 5(A)(4) Paris Convention 1883, as amended.

50 For a full list of requirements: Article 31, TRIPS Agreement.

51 Article 31(a) TRIPS Agreement. 
Secondly, a compulsory licence can only be granted if the proposed user of the licence had previously tried to obtain an authorisation for use of that technology from the patent-holder on reasonable commercial terms and conditions, and such efforts were unsuccessful within a 'reasonable period of time'. 52 A state can waive this requirement in 'the case of a national emergency or other circumstances of extreme urgency or in cases of public non-commercial use'. However, the rights-holder must be notified as soon as reasonably practicable in the context of a national emergency or situation of extreme urgency. Moreover, in the context of authorisation for public non-commercial use, the rights-holder 'shall be informed promptly'. 53

The COVID-19 context could likely fall within the definition of a national emergency, particularly if a state of emergency was declared by the country where the compulsory licence was sought (although an official declaration of a state of emergency is not necessarily required for this waiver to apply). ${ }^{54}$ Arguably, the fact that COVID-19 was declared a global pandemic by the WHO in March 2020,55 and as this pandemic continues this may be sufficient to constitute a national emergency for the purposes of Article 31(b) TRIPS Agreement. This is supported by the fact that the text of the Doha Declaration on the TRIPS Agreement and Public Health, para 5(c) states that:56

Each member has the right to determine what constitutes a national emergency or other circumstances of extreme urgency, it being understood that public health crises, including those relating to HIV/AIDS, tuberculosis, malaria and other epidemics, can represent a national emergency or other circumstances of extreme urgency [emphasis added].

Moreover, if there were a shortage of supplies of patented COVID-19 medicines, vaccines or diagnostics, this would arguably constitute a circumstance of extreme urgency given the likely threat to life such a shortage would pose within that state. In such circumstances, as in the case of a country seeking to provide COVID-19 medicines, vaccines or diagnostics to the public on a non-commercial basis, the requirement of having previously attempted to negotiate a licence with the patentholder could be waived.

52 Article 31(b) TRIPS Agreement.

53 Ibid.

54 For discussion of states of emergency in the COVID-19 context, see Alan Greene, 'State of emergency: how different countries are invoking extra powers to stop the coronavirus' (The Conversation, 30 March 2020).

'WHO Director-General's opening remarks at the media briefing on COVID-19' (11 March 2020).

56 See WTO, Ministerial Declaration of 14 November 2001, WTO Doc WT/MIN(01)/ DEC/1, 41 ILM 746 (2002) (hereinafter Doha Declaration). 
Third, the scope and the duration of the licence must be limited to the purpose for which it was authorised.57 This implies that, after a crisis has been averted - or in the case of a compulsory licence granted in the COVID-19 context, after the global pandemic has been deemed to have ceased - then the compulsory licence would need to terminated (or within a reasonable period after this). This could be problematic within the health context because if a compulsory licence ceases it would likely reintroduce access issues, transferring control back to the patent-holder and thereby affecting who can supply such health-technologies thereafter. It could also lead to an increase in costs and limits on the supply of such patented medicines, vaccines or diagnostics. This could have particularly significant implications for developing countries that have less access to resources/funds to secure access to such products.

Fourth, the authorisation or licence must be non-exclusive, meaning that the compulsory licence does not stop the patent-holder from licensing others to use the technology. 58

Fifth, any use under a compulsory licence is authorised 'predominantly for the supply of the domestic market' of the state where that use is authorised in. ${ }^{59}$ This requirement will effect countries that have limited manufacturing capacity to make patented vaccines, medicines or diagnostics domestically even if a compulsory licence were granted. The implications of this requirement were previously evident in the AIDS crisis during the 1990s, and as a result the Doha Declaration was adopted,60 and, subsequently, Article 31bis was introduced, which allows states to import patented inventions made under a compulsory licence elsewhere under certain circumstances. ${ }^{61}$ However, shortcomings remain in relation to such provisions which have been well documented elsewhere. ${ }^{62}$ Moreover, the EU has opted

\footnotetext{
57 Article 31 (c) TRIPS Agreement.

58 Article 31(d), TRIPS Agreement.

59 Article 31(f), TRIPS Agreement.

60 Paragraph 6 of which stated: '6. We recognize that WTO members with insufficient or no manufacturing capacities in the pharmaceutical sector could face difficulties in making effective use of compulsory licensing under the TRIPS Agreement. We instruct the Council for TRIPS to find an expeditious solution to this problem and to report to the General Council before the end of 2002.' Doha Declaration (n 56).

61 Article 31Bis, TRIPS Agreement, as amended. See Doha Declaration (n 56).

62 For a discussion, see Ellen 't Hoen, 'TRIPS, pharmaceutical patents and access to essential medicines: Seattle, Doha and beyond' (2002) 3(1) Chicago Journal of International Law; Duncan Matthews, 'WTO decision on implementation of paragraph 6 of the DOHA Declaration on the TRIPs Agreement and public health: a solution to the access to essential medicines problem?' (2004) 7 Journal of International Economic Law 73.
} 
out of this procedure which means an EU state cannot be an eligible importing member, which could prove highly problematic in the COVID-19 context - this is a serious and unnecessary shortcoming for compulsory licensing use within EU states discussed in detail in part five below.

Sixth, under the TRIPS Agreement the patent-holder must be paid adequate remuneration in each case. 63 This provision may deter states/ third parties from issuing compulsory licences, as there is uncertainty around how 'adequate remuneration' should be determined within states. 64 To facilitate better use of compulsory licensing, where public health demands it, further guidelines on how such remuneration should be determined would be useful, 65 alongside ensuring clarity on this at a national level - a point returned to below.

Seventh, the compulsory licence is liable to termination 'if and when the circumstances which led to it cease to exist and are unlikely to recur'. 66 Moreover, the 'competent authority shall have the authority to review, upon motivated request, the continued existence of these circumstances'.67 Thus, the grant of such a licence can and indeed should be subject to periodic review to ascertain if the circumstances for grant still pertain. This implies that compulsory licensing provisions are time-limited in nature, and, for example, if COVID-19 was no longer considered a global pandemic or a national emergency (if this was the basis on which such a licence was granted), then that licence shall be liable to termination. Similarly, if a licence were granted in circumstances of urgency, once these circumstances dissipated then the licence would be liable to termination.

From the foregoing, it is thus evident that these culminative minimum WTO criteria present constraints on the use of compulsory licensing which may impede their effectiveness in alleviating access issues posed by patents for COVID-19.68 Most notably, from the above, the provisions around the need for adequate remuneration for the rightsholder could deter applicants/states in using compulsory licensing, unless greater guidance is evident on how this would be

63 Article 31(h), TRIPS Agreement.

64 See discussion in Antony Taubman, 'Rethinking TRIPS: "adequate remuneration" for non-voluntary patent licensing' (2008) 11(4) Journal of International Economic Law 927-970.

65 WHO guidelines on this and proposals for how remuneration could be calculated are available at: James Love, Remuneration Guidelines for Non-voluntary Use of a Patent on Medical Technologies WHO/TCM/2005.1 (WHO 2005).

66 Article 31(g) TRIPS Agreement.

67 Article 31(g) TRIPS Agreement

68 See also Frederick M Abbott and Rudolf Van Puymbroeck, 'Compulsory licensing for public health: a guide and model documents for implementation of the Doha Declaration paragraph 6 decision' (2005) World Bank Working Paper 61. 
determined. Furthermore, the need to grant a compulsory licence on a case-by-case basis for each patented invention means compulsory licensing does not offer a catch-all solution for addressing access issues on, for example, health-technologies for COVID-19. Nonetheless, taking a pragmatic view, it is likely to be difficult to successfully petition for any change of such TRIPS provisions, given that this would require a change of WTO law, which is fraught with difficulty given the need for multiple states' agreement, and, even if successful, any such change would likely take years to achieve. Furthermore, as noted, such conditions offer a balance to ensure interference with rightsholder's patent rights is not disproportionate. Thus, changing WTO law is not likely a feasible solution within the COVID-19 pandemic context, although addressing some of these shortcomings should not be abandoned in the longer term as doing so would facilitate states to offer a more effective system for compulsory licensing at the national level in future where public health requires such interventions.

Nonetheless, whilst WTO states including Ireland must abide by these international TRIPS and Paris Convention standards, national frameworks require consideration to ensure that compulsory licensing provisions are not going beyond the requirements set out within the TRIPS and Paris Convention, if the aim is to ensure compulsory licences offer effective mechanisms where needed to facilitate access to patented health-technologies. Changes to national laws are feasible within a shorter period of time, and, indeed, since COVID-19 many national states have already adopted legal measures to amend national laws on compulsory licensing to ensure such licences are easier to obtain if required in the COVID-19 context.69 Ireland should follow suit, removing national obstacles to effective uses of compulsory licensing for COVID-19 and for public health more generally.

\section{COMPULSORY LICENSING IN IRELAND AND COVID-19: AN APPRAISAL AND PROPOSAL FOR REFORM}

This section offers an overview of the current applicable framework for compulsory licensing in Ireland, and the main shortcomings of this framework, focusing specifically on how compulsory licensing under the current framework could be used to alleviate access issues posed by patents for COVID-19 health-technologies. It then sets out reform proposals to offer a more effective system for compulsory licensing in Ireland.

Prior to delving into the analysis of such provisions, it is important to note two points. Firstly, compulsory licensing provisions operate in 
Ireland alongside a government-use provision, allowing state use of a patented invention where needed for 'services of the State' (examined in part four below). These two avenues should be viewed as a package of complementary measures which operate together to permit interventions with patent-holder's control over patented inventions where needed to alleviate access issues arising.

Secondly, on first view, considered together, the texts of these legal provisions on compulsory licensing and licensing for service of the state in Ireland, although as will be seen they do not refer to public health or the public interest explicitly, nonetheless appear to offer scope for intervention with patent-holder discretion, particularly, because many of the provisions related to compulsory licensing and licences for 'service of the State' are drafted in a broad 'open-textured' manner.70 Thus, one could argue, that because of the relatively expansive nature of some of these provisions (and particularly the service of the state provisions), they could in theory allow a broad interpretation, including for such provisions in their current form to be used, in some circumstances, to alleviate access issues in a pandemic context.

However, two issues arise in this context which support the need for reform. Firstly, Irish law contains instances where higher standards for compulsory licensing have been adopted than are needed to comply with minimum TRIPS standards. As will be seen, this limits the scope for use of such licences than could be possible in the COVID-19 context, and reforms are needed to address this.

Secondly, given the historical reluctance of states to issue compulsory licences, such expansive open-textured legislative provisions as they exist in the Irish context which fail to expressly refer to the use of these provisions in the health or pandemic context, and which require the Controller of Intellectual Property in Ireland or courts to interpret the measures as applying in the pandemic context, are problematic. This is because 'thought styles', ${ }^{71}$ or interpretative communities, 72 whereby shared understandings or predispositions in favour of particular actions/interpretations may arise within such interpretative contexts. Within such contexts, the past actions within a decision-making framework can affect future decision-making, and such influences

70 Open-textured provisions are defined by Hart as 'statutes may be a mere legal shell and demand by their express terms to be filled out with the aid of moral principles'. See H L A Hart, The Concept of Law (Oxford University Press 1961) 199-200. See discussion in Aisling McMahon, 'Morality provisions in the European patent system: an institutional examination' (PhD Thesis, University of Edinburgh, 2016).

71 Mary Douglas, How Institutions Think (Syracuse University Press 1986).

72 Peter Drahos, 'Biotechnology patents, markets and morality' (1999) 21(9) European Intellectual Property Review 441-442. 
can be particularly acute where decision-makers have considerable discretion over open-textured or expansive provisions. ${ }^{73}$ In the institutional context, this is discussed in terms of 'path dependency' which implies that historical actions influence present acts, 74 or in simple terms that "what happened at an earlier point in time will affect the possible outcomes of a sequence of events occurring at a later point in time'. ${ }^{75}$ In essence, this implies that how a particular issue or provision (or an analogous issue) has been dealt with in the past by the institution will be influential, but not necessarily determinative, of present action(s). ${ }^{76}$

Accordingly, in situations where there has been a historical reluctance to interpret open-textured provisions in a manner which limits patent rights, 77 or where there has been historically limited use of such provisions to intervene with patent-holder discretion over licensing, this status quo of non-intervention and hence non-use/ grant of compulsory licences is likely to be maintained unless change is encouraged by external action, such as by legislative reforms which specify that such provisions can be used in public health or pandemic contexts. In Ireland, there have been no compulsory licences issued to date in such contexts under section 70 of the Patents Act 1992 (as amended) (hereafter PA), and, similarly, the service of the state provision has received limited attention or use. Hence, leaving such provisions in their current form, without legislative intervention or guidance that expressly indicates the use of such provisions is possible within the public health and/or in a pandemic or epidemic context, is arguably likely to result in the status quo remaining and entrench a lack of willingness to use or interpret these provisions as applying in the public health context in Ireland.

For these reasons and for the specific reasons given below, legislative change is urgently needed to clarify the operation of these provisions in the public health context and to address specific shortcomings within the current framework.

73 See generally McMahon (n 70).

74 See O Hathaway, 'Path dependence in the law: the course and pattern of legal change in a common law system' (2001) 86 Iowa Law Review 101.

75 W H Sewell Jr, 'Three temporalities: toward an eventful sociology' in T McDonald, (ed), The Historic Turn in the Human Sciences (University of Michigan Press 1996) 245, 262-263.

76 See McMahon (n 70); Aisling McMahon, 'Regulatory authorities and decisionmaking in health research: the institutional dimension' in Graeme Laurie et al (eds), Cambridge Handbook of Health Research Regulation (Cambridge University Press 2021).

77 See McMahon (n 70). 


\subsection{Compulsory licensing in Ireland}

Section 70 of the $\mathrm{PA}^{78}$ sets out the main criteria for the grant of a compulsory licence in Ireland. It provides that any person can apply for a compulsory licence to the Controller of Intellectual Property in Ireland, ${ }^{79}$ (hereafter Controller) based on two main grounds namely:

1. on the basis of demand in the Irish state:

a. 'a demand in the State for the subject matter of the patent is not being met or is not being met on reasonable terms'; 80 or

b. demand in the Irish state for the patented product is 'being met by importation other than from a member of the World Trade Organization'; 81

2. that the 'establishment or development of commercial or industrial activities in the State is unfairly prejudiced'. 82

Of these grounds, the first ground is the ground most likely applicable in the COVID-19 context. However, the fact that grant of a compulsory licence in Ireland under this ground is premised on the demand for the invention in the state could pose an obstacle to the use of a compulsory licence, as assessing 'demand in a State' is a relatively subjective assessment. Under previous case-law, 'demand' in this context has been understood to mean public demand. 83 However, this would likely be construed as the actual demand at the price provided by the patentholder not demand if the invention was provided at a lower price. 84 In the pandemic context, demand is likely to be high even if a vaccine, medicine or diagnostic is charged at high prices, given that access to this health-technology is required to meet a pressing health need. Thus, the need to show actual demand is not likely to be an obstacle. However, it is unclear what threshold is needed to show that demand is not being met under this ground. Arguably, unless a significant shortage of the patented invention were evident it may be difficult to justify a compulsory licence on this ground. Nonetheless, the lack of clarity around what is likely to constitute a failure to meet demand or failure to meet demand on 'reasonable terms' (or whether this could

78 This was amended by the Patent (Amendment) Act 2006; see also Patent Rules 1992, as amended, of which rule 50 applies in the context of compulsory licences.

79 The name of the Controller was changed from 'Controller of Patents Designs and Trade Marks' to the 'Controller of Intellectual Property' from December 2019, and this was amended in the Patents Act 1992, by virtue of section 42 of the Copyright and Other Intellectual Property Law Provisions Act 2019.

80 Section 70(1)(a)(i) PA.

81 Section 70(1)(a)(ii) PA.

82 Section 70 (1)(b) PA.

83 Boult's Patent (1909) 26 RPC 383 as cited in Clark et al (n 12) 201.

84 Ibid 201. 
plausibly include a consideration of the price the invention is provided for) could deter applications or authorisations for compulsory licences in Ireland.

Alongside these two main grounds, a compulsory licence can also be obtained if a patent-protected invention (the second patent) cannot be used in a state without infringing upon rights from another patent (the first patent) - in such cases the patent-holder of the second patent can apply to the Controller for a licence under the 'first patent to the extent necessary for the exploitation of the invention concerned, provided that such invention involves an important technical advance of considerable economic significance in relation to the invention claimed in the first patent'. 85

Overall, these grounds for compulsory licensing in Ireland are relatively restrictive in nature, even though, as noted above, the Paris Convention and the TRIPS Agreement provide considerable discretion to states in setting the grounds for compulsory licences. The restrictive nature of these grounds forms the first potential roadblock within Irish laws to providing an effective mechanism for compulsory licensing in the health context, and this is returned to in section 3.2 below.

Relatedly, section 70 PA, as amended, specifies that compulsory licences can only be granted three years after the publication of notice of the grant of a patent in Ireland.86 This mirrors the criteria for the grant of compulsory licences in cases of 'failure to work or insufficient working' of a patent under the Paris Convention, discussed above. This condition of time within the Paris Convention allows the patent-holder sufficient time to show they are exploiting the patent and hence are not failing to work an invention. ${ }^{87}$ However, in the Irish context, the reference to this time restriction covers all grounds for compulsory licensing and is not restricted to the context of 'failure to work' a patented invention, the context where this time-limit is specified as applying under the Paris Convention. This is an example of an additional restriction within Irish law beyond those which are required by the international legal framework applicable. To be compliant with international laws, it would be sufficient for Irish law to include this

85 Section 70(2) PA.

86 Section 70(1) PA states: 'At any time after the expiration of the period of three years, or such other period as may be prescribed, beginning on the date of the publication of notice of grant of a patent any person may apply to the Controller for a licence under the patent, or for an entry in the register to the effect that licences under the patent are to be available as of right ....

Van Zimmeren and Van Overwalle (n 46) 17. 
time restriction only in relation to a ground of grant of a compulsory licence based on failure to work an invention. 88

This time restriction is potentially an obstacle to the use of compulsory licensing for COVID-19 related health-technologies, as it limits the state's ability to grant a compulsory licence for newly developed patented technology in Ireland. Generally, within the health-context, the regulatory approval process for new medicines or vaccines takes considerable time, often well beyond three years. 89 Thus, ordinarily having to wait until three years after patent grant to apply for a compulsory licence over a health-technology may not in practical terms pose a significant obstacle to accessing this technology. However, time is of the essence for COVID-19. There is a global effort to develop effective and safe medicines and vaccines for COVID-19 as soon as possible, yet this three-year requirement means that, even if there is such a medicine or vaccine, if it is under patent no compulsory licence can be applied for until three years post-grant. This obstacle should be removed as soon as possible outside the circumstances of where it is required under the Paris Convention (i.e. failure to work a patent). As having this time restriction for all grounds of compulsory licensing in Ireland unnecessarily ties the hands of the government for newly patented medicines/vaccines/diagnostics.

Turning then to the terms upon which the grant of a compulsory licence is made in Ireland, if the Controller is satisfied the grounds for a compulsory licence are met, according to section 70(3) PA the licence can be granted with the following main conditions:

- it would be a non-exclusive licence;

- it would be granted predominantly for the supply of the domestic market in Ireland;

- the licence granted can only be assigned with prior authorisation of the Controller and under specific conditions;

- the licence is granted subject to the payment to the patent-holder of 'adequate remuneration in the circumstances of the case, taking into account the economic value of the licence'. In this context, it is questionable how the adequacy of remuneration is to be determined, including how the 'economic value' of the licence

88 There was such a specific ground under Irish patent law, under section $70(2)$ (a) of the Patents Act 1992 which stated that: '(2) The grounds referred to in subsection (1) are the following: (a) that the invention which is the subject of the patent, being capable of being commercially worked in the state, is not being commercially worked therein or is not being so worked to the fullest extent that is reasonably practicable.' This was deleted by section 19, Patents Amendment Act 2006.

89 Stuart A Thompson, 'How long will a vaccine really take?' New York Times (New York, 30 April 2020). 
is to be calculated, which could lead to uncertainty and potential challenge. Providing guidelines on this within Ireland would be useful to ensure this is not a roadblock to use of compulsory licensing if needed for COVID-19;

- the licence granted would be limited in terms of the scope and purpose for which it is granted. 90

Many of these requirements merely reiterate the minimum requirements set out under the TRIPS Agreement considered above and are necessary to ensure Ireland's compliance with such international obligations.

In granting a compulsory licence under the Act, the Controller shall take account of the following matters:

a. the nature of the relevant invention, the time which has elapsed since the grant of the patent and the measures already taken by the proprietor or any licensee to make full use of the invention,

b. the ability of any person to whom a licence would be granted under the order to exploit the patent to the public advantage, and

c. the risks to be undertaken by that person in providing capital and exploiting the patent if the application is granted. ${ }^{91}$

These aspects imply a focus on the supply of the invention within the country by the patent-holder and suggest a need to allow the patent-holder time to develop sufficient supply of the invention. This condition likely relates to the narrow grounds currently in operation for compulsory licensing in Ireland. However, significantly, this section does not reference any public need or the public interest more generally, and, arguably, including a reference to demand to meet public need/interest would be preferable should compulsory licences be required for public health purposes.

Section 72 PA expressly provides that a Minister of the Irish government can apply for a compulsory licence under any of these above grounds set out under section 70 'after the expiration of the period of three years beginning on the date of the publication of notice of grant of a patent, or such other period as may be prescribed under section 70(1)' where section 70(1) provides that it can also be after 'such other period as may be prescribed'. Presumably, this caveat in section 70(1) allows the government to adopt legislative measures which would adopt an alternative period which could be used to reduce the time needed in circumstances outside of cases where compulsory licences are being used to address failure to work or failure to work the patent on sufficient basis.

Under section $72 \mathrm{PA}$, the minister can apply for the entry in the patent register to the effect that: 
... licences under the patent are available as of right, or for the grant to any person specified in the application of a licence under the patent, and the Controller may, if satisfied that any of those grounds are established, make an order in accordance with the application.92

Thus, section 72 PA allows, for example, a health minister to apply for a compulsory licence for medicines/vaccines or other technology necessary in the COVID-19 context.

In terms of the practical application process for a compulsory licence, applicants apply to the Controller and provide a statement which sets out the facts of the application including 'evidence indicating that the applicant sought to obtain a licence' from the patent-holder but was unable to obtain such a licence on 'reasonable terms and within a reasonable time'.93 The Controller 'may, when so requested' (emphasis added) by the applicant dispense of this requirement for evidence if 'there exists a national emergency or other circumstances of extreme urgency' or 'in the case of an application for a licence for public noncommercial use' provided that the patent-holder has been 'informed as soon as reasonably practicable of the intention of the applicant to apply to the Controller for licence under patent'. 94 This mirrors provisions allowing for waiver of the requirement of attempting to negotiate access with the patent-holder in cases of emergency, urgency or public non-commercial use as set out in TRIPS.

\subsection{Reform proposals}

In short, based on the foregoing analysis, to facilitate greater effectiveness of the compulsory licensing mechanisms within Ireland for the COVID-19 context and for public health more generally, it is proposed that four main aspects of the current national framework be reconsidered, namely two legislative changes and two areas where further guidance on how legislative provisions are interpreted in practice would be useful

In the context of legislative reforms: firstly, it is vital that the requirement to wait for three years after the patent grant to apply for a compulsory licence is reconsidered. This requirement is only necessary under the Paris Convention in cases where a patent is applied for based on failure of the patent-holder to work the patent, or insufficient working of the patent.95 However, the time restriction has been applied for all grounds of compulsory licensing applicable in Ireland under section $70 \mathrm{PA}$, thereby going beyond what is needed for Ireland to comply with international law, and this should be amended. This

92 Section 72(1) PA.

93 Section 73(1) PA.

94 Section 73(1A) PA.

95 Article 5(A)(4) Paris Convention. 
could be achieved by amending section 70(1) of the Act. Alternatively, currently, section 70(1) PA provides that it is a three-year term 'or such other period as may be prescribed', implying this could be amended relatively easily by prescribing a shorter term by virtue of, for example, a statutory instrument. For the reasons given above, reducing this term is needed to ensure the Irish government's hands are not tied in using compulsory licensing for newly patented inventions. This time restriction should therefore be removed under Irish law for all grounds of compulsory licensing, other than in cases where the licence is granted on the basis of failure to work a patent or failure to work it sufficiently within Ireland. Thus, alongside amending section 70(1) to remove the time restriction, to ensure compliance with the Paris Convention, the Act could reintroduce a ground which expressly referred to the grant of a compulsory licence in the case of failure to work a patent or insufficient working of a patent 96 and should, in that context, include a provision which stated: 'in cases where a compulsory licence is granted on the basis of failure to work or insufficient working of a patent, such a licence shall only be granted 3 years after publication of notice of patent grant'.

Secondly, and relatedly, the grounds allowing for compulsory licences in Ireland could be expanded to include a broader catchall ground relevant to the public interest/public health context. For example, a ground could be included which allowed for a compulsory licence where 'necessary for the public interest'. A non-exhaustive list should also be given within such an amendment, providing that it would apply, 'for example, in cases of national emergency, including, within a public health crisis (e.g. a pandemic), environmental emergency, or economic crisis'. As noted above, expressly referring to such measures as applicable in the public health context, including in a pandemic context, within the legislative framework would provide an explicit source referring to the use of such measures in the public health context, which could encourage greater willingness to use provisions where needed for COVID-19. Expanding the text to include examples such as use in an environmental emergency, economic crisis etc. would provide greater longevity for the proposed reform expressly confirming its use, where public interest required it, in other contexts. However, adopting

96 As noted above, a ground which expressly referred to failure to work an invention was evident in the Patents Act 1992 but was removed by the Patents Amendment Act 2006 in favour of a more generally worded ground related to demand in the state. Section 70(2)(a) Patents Act 1992 previously provided the following ground for a compulsory licence: 2(a) 'that the invention which is the subject of the patent, being capable of being commercially worked in the State, is not being commercially worked therein or is not being so worked to the fullest extent that is reasonably practicable'. 
a broad provision of this kind may be opposed by industry, and an alternative would be to adopt a provision which allowed compulsory licensing where necessary for public health grounds, with a legislative provision specifying that an epidemic or pandemic context constitutes an example of public health grounds. ${ }^{97} \mathrm{Or}$, alternatively, given that compulsory licensing and service of the state provisions operate as a package in Ireland, one solution would be to refer expressly to the public health context only under patents for 'service of the State' and not in the general compulsory licensing context. However, such an approach would unnecessarily confine the grounds within which licences could be granted for public health purposes, requiring service of the state provisions to be fulfilled, and this would fail to facilitate the use of compulsory licensing more broadly on this basis. It would also fail to facilitate third parties applying for compulsory licences on public health grounds, as licences for service of the state relate primarily to government use of such provisions.

Turning then to the need for further guidance: thirdly, certain aspects of the current grounds would benefit from further guidance, specifically under section 70(a) PA, guidance is needed on how 'demand' for the invention in the state will be assessed in practice, including what threshold is needed. Greater clarity is also needed around how whether an invention is being provided on 'reasonable' terms will be considered in practice, and how 'reasonableness' will be assessed.

Fourthly, and finally, guidelines should be issued within Ireland on how the requirement of adequate remuneration for a compulsory licence will be assessed in a particular context, ensuring any uncertainty in this context does not act as a deterrent to applicants in applying for compulsory licences or the approval of such licences. Whilst remuneration must be decided on a case-by-case basis in practice, having a statement on the overarching general principles applicable within Ireland on this, and raising awareness of the mechanisms used to determine this or general principles applicable, would arguably be useful to encourage greater recourse to such provisions, where needed.

The need for such legislative reforms and guidance around existing provisions under Irish law is compounded by the fact that the grant or applications for compulsory licences have historically been uncommon/ non-existent in practice. 98 Thus, there is limited jurisprudence on compulsory licensing to draw on to give further clarity in the Irish context. Moreover, patent legislation in Ireland has been amended

97 Other countries have adopted such provisions in light of COVID-19. See, generally, Wong (n 37).

98 There are no official statistics on this in Ireland: see European Patent Academy, Compulsory Licensing in Europe: A Country-by-Country Overview (European Patent Office, 2018) 63. 
several times since the Patent Act's adoption in 1992, including a relatively substantial amendment of the compulsory licensing provisions in 2006 to bring Ireland's laws in line with the TRIPS Agreement. Thus, any case law which does exist will likely be of limited use in determining the application of recently revised provisions. Moreover, whilst, the law in the UK is likely to be persuasive, given its similar wording to much of the current Irish patent legislation, 99 nonetheless, to introduce greater clarity in the area, further domestic guidance would be beneficial.

\section{LICENSING FOR SERVICE OF THE STATE IN IRELAND: ACCESS TO HEALTH-TECHNOLOGIES AND COVID-19}

Alongside the compulsory licensing provisions applicable under Irish law, section 77 PA provides for the right to use patented inventions in Ireland without the patent-holder's permission for 'service of the State' - this is effectively a government-use provision (akin to the crownuse within UK law). ${ }^{100}$ This provision allows a government minister or person authorised by them powers to do any of the following acts without the consent of the patent-holder:

(a) where the invention is a product, make, use, import or stock the product or dispose of or sell or offer to dispose of or sell it to any person;

(b)where the invention is a process, use it or do in relation to any product obtained directly by means of the process anything mentioned in paragraph (a);

(c) supply or offer to supply to any person any of the means, relating to an essential element of that invention, for putting the invention into effect. ${ }^{101}$

This mechanism provides a relatively broad avenue within which use of a patented technology can be sought by the government without the patent-holder's consent and this could be useful within the COVID-19 context. Any of the above acts if conducted under this provision do not amount to patent infringement. ${ }^{102}$

99 See discussion ibid.

100 For a discussion of the operation of crown-use in the context of COVID-19, see Karen Walsh, Andrea Wallace, Mathilde Pavis, Natalie Olszowy, James Griffin and Naomi Hawkins, 'Intellectual property rights and access in crisis' (Working Paper 2020) (on file with author). Other countries have similar crown or government-use provisions, for a list of such measures and their use in the COVID-19 context to date, see COVID-19 IP Policy Tracker. For a general discussion of these provisions under Irish law, see: Clark et al (n 12) [8.46][8.53].

101 Section 77(1) PA.

102 Section 77(2) PA. 
The use of the invention under this section for 'service of the State' is defined as 'a service financed out of moneys charged on or advanced out of the Central Fund or moneys provided by the Oireachtas or by a local authority for the purposes of the Local Government Act, 1941'.103 Arguably, this would undoubtedly include Irish health services, given the public nature of such services in Ireland as provided by the Health Services Executive (HSE). In terms of renumeration, the TRIPS Agreement provides that a state can set out specific circumstances where it can use a patented invention without the patent-holder's consent, provided 'adequate' remuneration is paid to the rightsholder. ${ }^{104}$ The PA provides that use of the invention under this section is subject to terms which may be agreed upon 'either before or after the use' with the approval of the Minister for Finance, by any government Minister and the applicant for the patent or the patent-holder. ${ }^{105}$ Presumably, this also includes agreement on the terms of remuneration which could therefore be concluded before or after use under this section. In default of an agreement, or in the event of dispute, the matter would be settled under the Act by the appropriate court or by an arbitrator upon conditions they may direct.106 However, a shortcoming within this process is if the terms of remuneration for the patent-holder were not concluded until after the use takes place, and, if there is uncertainty around the principles applicable for how remuneration is calculated, the government would not know how much it would likely cost to use this licensing mechanism, and this could potentially lead to a government's reluctance to use this provision, as high costs could arise. ${ }^{107}$ Similar, to the compulsory licensing context, such issues would be alleviated to some extent by guidelines being provided at a national level around the overarching principles applicable for how remuneration would

103 Section 77(10) PA.

104 Article 31(h) TRIPS Agreement, as amended. See discussion in Clark et al (n 12) 8.48 .

105 Section 77(3) PA.

106 Section 77(6) PA. Use of an invention for service of the state can be used without renumeration under the circumstances of section 77(4) PA which provides: ‘(4) Where an invention which is the subject of any patent or application for a patent has, before the date of filing, or, where priority is claimed, the priority date of the application, been duly recorded in a document by, or been tried by or on behalf of any Minister of the Government (such invention not having been communicated directly or indirectly by the applicant for or the proprietor of the relevant patent), any Minister of the Government or such of his officers, servants or agents as may be authorized in writing by him, may use the invention so recorded or tried for the service of the State free of any royalty or other payment to the applicant for or the proprietor of the patent, notwithstanding the existence of the application or patent ...'

107 For a discussion of the analogous Crown use provision in the UK context, see Walsh et al (n 100). 
likely be calculated or factors which would be considered within this process in Ireland. This could act as a useful toolkit in deciding adequate remuneration and would introduce greater clarity on these issues, thereby making it more likely that a government would use these provisions if needed.

Section 78(1) PA provides for additional extended provisions for uses of inventions for service of the state in exceptional circumstances, whereby the state can use patented inventions for any purposes where it appears necessary or expedient to a minister of the government for: 'a) maintenance of supplies and services essential to the life of the community; b) for securing a sufficiency of supplies and services essential to the well-being of the community ... f) for ensuring the public safety and the preservation of the State'. Although, the text of these provisions does not expressly refer to public health or the public interest, it is highly likely in theory that such provisions would be applicable within the COVID-19 context given the global pandemic we face, as it is likely that supplies of diagnostics, treatments or vaccines for COVID-19 would be viewed as supplies which were 'essential to the life of the community' and/or 'essential to the well-being of the community' and/or for 'the preservation of public safety in the State'. Thus, such grounds could potentially offer an effective avenue to gain access to such patented technology where necessary for COVID-19.108

However, the thresholds applicable under these circumstances would again benefit from further guidance. In particular, the use of these provisions (a) and (b) when applied to the COVID-19 context would likely rest on whether adequate supplies of a patented healthtechnology were available in the country. Yet, it is questionable how the notion of 'sufficiency of supplies' in this context would be interpreted. Greater legislative guidance on the threshold applicable would be useful in the event that this provision is needed for COVID-19 or within other health contexts in future. 109

A further issue is that section 78(2) indicates the powers to use a patented invention for service of the state under the section $78(1)$ provision would only be invoked in exceptional circumstances. It states that: 'Where the Government are of the opinion that, owing to the existence of exceptional circumstances, it is desirable in the interests of the community that a power conferred by subsection 1 shall be available, they may by order declare that the power shall be available.'

108 Notably, in Evalve \& Abbott $v$ Edwards Lifesciences Limited [2020] EWHC 513 (Pat), [77] where the similar UK mechanism of crown-use was raised: the court noted that an example of where this provision would be applicable was for the provision of life-saving generic medicines in the public interest in 'special cases, such as novel pandemic disease'. See discussion in Walsh et al (n 100).

109 See discussion in Kelly (n 21). 
(emphasis added)110 This current phrasing explicitly suggests use under section 78(1) grounds will only be in rare circumstances, ${ }^{111}$ which may prove a considerable impediment to use of this mechanism as it suggests a very high threshold is needed if it is only to be used in 'exceptional circumstances'. It is proposed that legislative change is needed and the phrase the 'existence of exceptional circumstances' in this section be amended to indicate 'Where the Government are of the opinion that, it is necessary in the interests of the community that a power conferred by subsection 1 shall be available, they may by order declare that the power shall be available.' This should be accompanied within the legislation by a non-exhaustive list of examples of what interests of the community may include, with express reference to public health contexts, including a public health emergency such as a pandemic/epidemic etc.

Without adopting such changes, it is still likely that the global pandemic caused by COVID-19 would fall within exceptional circumstances suggested within section $78 \mathrm{PA}$, but expressly providing within legislation that a pandemic or epidemic comprises a circumstance where such licences if needed would fall within the interests of the community would arguably encourage greater clarity and, hopefully, result in greater state willingness to use such provisions where needed. Removing the term 'exceptional circumstances' would also potentially encourage greater recourse to this provision. Nonetheless, the elephant in the room may be the remuneration required if a licence were issued under this provision - and guidance on how this is determined is therefore vital.

\section{EU OBSTACLES TO EFFECTIVE USE OF COMPULSORY LICENSING}

Alongside these national reform proposals, it is also vital that some of the current obstacles stemming from EU law to the effective practical use of compulsory licensing in the health context within EU states are amended.112 Most notable in this context are existing legal protections which pose difficulties for the registration of generic medicines (medicines which are similar/identical to the branded/patented version) that are produced under compulsory licences, namely data exclusivity protections and marketing exclusivity protections. Under

110 Section 78(2(a) PA.

111 See also discussion in Ann Henry, 'Coronavirus: patents rights and the public interest' (Pinsent Masons, Out-Law, 3 April 2020).

112 Ellen 't Hoen, 'European pharmaceutical legislation needs exceptions to data and market exclusivity to protect European patients from high drug prices' (Medicines Law and Policy, 21 May, 2018). 
EU law, there is an eight-year data exclusivity protection which applies to all new medicines ${ }^{113}$ - this effectively means that within this time period someone who, for example, produces a generic medicine under a compulsory licence would be unable to use the original clinical data conducted for the patented medicine's approval to support the application for generic approval. Having to conduct additional clinical studies would be both costly and time prohibitive for a generic producer and could effectively defeat the purpose of granting a compulsory licence as, in practice, although it could mean the licence to allow a third party to produce a generic version is granted, it would be difficult to gain approval for generics made under the compulsory licence. There is currently no explicit waiver on the data exclusivity protection where a medicine is subject to a compulsory licence.114 This is a major regulatory stumbling block to the use of compulsory licensing in the EU for COVID-19 and other health contexts. Furthermore, marketing exclusivity applies, which means that a generic medicine cannot be marketed until 10 years after the original medicine obtained authorisation. ${ }^{115}$ There is also no exception to this marketing exclusivity protection under EU law in cases of compulsory licensing. Such data and marketing exclusivity protections deterred Romania's use of a compulsory licence in 2016 for sofosbuvir to treat hepatitis C.116 In order for compulsory licensing measures to be an effective avenue in EU countries for health-technologies, it is crucial that a waiver is introduced to such protections in this context.

113 See Regulation (EC) No 726/2004 of the European Parliament and of the Council of 31 March 2004 laying down Community procedures for the authorisation and supervision of medicinal products for human and veterinary use and establishing a European Medicines Agency OJ L 136, 30.4.2004, Article 14(11) which states: 'Without prejudice to the law on the protection of industrial and commercial property, medicinal products for human use which have been authorised in accordance with the provisions of this Regulation shall benefit from an eightyear period of data protection and a ten-year period of marketing protection, in which connection the latter period shall be extended to a maximum of 11 years if, during the first eight years of those ten years, the marketing authorisation holder obtains an authorisation for one or more new therapeutic indications which, during the scientific evaluation prior to their authorisation, are held to bring a significant clinical benefit in comparison with existing therapies.'

114 See discussion in Houldsworth (n 11). See also, generally, discussion of data exclusivity and compulsory licensing in Phoebe Li and Pheh Hoon Lim, 'A precautionary approach to compulsory licencing of medicines: tempering data exclusivity as an obstacle to access' (2014) 3 Intellectual Property Quarterly 241.

115 Article 14(11) Regulation 726/2004.

116 E 't Hoen, P Boulet, B Baker, 'Data exclusivity exceptions and compulsory licensing to promote generic medicines in the European Union: a proposal for greater coherence in European pharmaceutical legislation' (2017) 10 Journal of Pharmaceutical Policy and Practice 19. 
Finally, there are obstacles to Ireland to importing medicines manufactured under compulsory licence in another country where needed for COVID-19. As noted above, Article 31 of the TRIPS Agreement allows for compulsory licensing, but it requires that such licences are used predominantly for the supply of the domestic market within the state that the licence is granted within. ${ }^{117}$ This can be highly problematic as, for example, in the developing-country context states may not have the domestic manufacturing capacity to produce generic versions of medicines under compulsory licence in the state. To address this, a wavier to this domestic production requirement for compulsory licensing was introduced by Article $31 \mathrm{bis}$, which allows states to produce generic versions of health-technologies made under compulsory licence to be exported to states that require them but do not have the manufacturing capacity to produce these domestically, subject to certain requirements. This waiver was first introduced on a temporary basis on 30 August 2003; it was then approved as an amendment to the TRIPS Agreement in 2005, and finally ratified by the required number of WTO states, to enter into force in January 2017. This waiver is the only avenue by which states can import generic versions of patented medicines from another state where public health demands it, whilst remaining compliant with the TRIPS Agreement.

This provision is coming under the spotlight again in the COVID-19 context, for two reasons: 1) as has been seen already, COVID-19 can cause devastating health impacts within a region, and this in turn could impact domestic industries including pharmaceutical production. Thus, states that ordinarily have a strong pharmaceutical industry could find this halted by COVID-19 or other public health contexts, making it impossible to produce sufficient generics domestically even if a compulsory licence were granted. 2) States may lack domestic supplies of pharmaceutical ingredients necessary to make generic medicines for COVID-19, again rendering domestic manufacture of COVID-19 health-technologies under compulsory licence impossible.

Importantly, although historically this provision was most relevant to developing countries and least developed countries that lacked manufacturing capacity, it can be used by any WTO state that has notified the WTO that it is an eligible importing state, whereby 'it being understood that a Member may notify at any time that it will use the system in whole or in a limited way, for example only in the case of a national emergency or other circumstances of extreme urgency or in cases of public non-commercial use'. ${ }^{118}$ However, the Annex to this provision also states that 'some Members will not use the system as importing

117 Article 31(f) states that: 'any such use shall be authorized predominantly for the supply of the domestic market of the Member authorizing such use'.

118 Annex to the TRIPS Agreement, paragraph 1(b). 
Members, and that some other Members have stated that, if they use the system, it would be in no more than situations of national emergency or other circumstances of extreme urgency' (emphasis added).

The EU is one such region that has voluntarily opted-out of the WTO framework, and therefore EU states are not eligible importing states, meaning the EU or member states cannot currently import generics made under compulsory licence elsewhere under Article 31bis. ${ }^{119}$ Ireland has a strong pharmaceutical industry, and thus, ordinarily, this opt-out decision would be unlikely to pose an issue as there should be sufficient capacity/skills to produce generic medicines made under compulsory licence domestically. However, in the context of a global pandemic which can have devastating impacts on human health, 120 with further impacts on supply chains, 121 this could conceivably hinder any country's ability to continue pharmaceutical operations. Therefore, despite Ireland's ordinarily strong pharmaceutical manufacturing capabilities, it is highly plausible Ireland could need to utilise this measure for COVID-19 or future health crises. Thus, it is vital this optout decision for EU states is changed, as James Love has noted in this context, it is:

... totally irrational for any country, even a rich country, to keep its own hands tied to meet the COVID-19 needs of its population by voluntarily shutting itself off from patented ingredients, components, and essential medical products and supplies. ${ }^{122}$

There are calls for the EU to change this restriction, and the Irish government and other national EU Member State governments should support such calls to demand change on this as a matter of urgency. ${ }^{123}$ The opt-out should either be revoked in its entirety if possible, or the EU should ensure a provision is included within this opt-out which allows such imports in cases of "national emergency or other circumstances

119 'Implementation of paragraph 6 of the Doha Declaration on the TRIPS Agreement and public health General', Council Decision, Article 1(b), footnote 3; Article 31 bis, Annex, Article 1(b), footnote 3.

120 At the time of writing, 4 September 2020, COVID-19 had resulted in over 873,000 deaths worldwide, with 26.5 million cases. See Worldometer.

121 See discussion in Anthony Lakavage, 'Covid-19 has exposed cracks in the global medicines supply chain. We need to fix them’ (Stat News, 2 June 2020).

122 James Love, 'Open letter asking 37 WTO Members to declare themselves eligible to import medicines manufactured under compulsory licence in another country, under 31bis of TRIPS Agreement' (Knowledge Ecology International, 7 April 2020).

123 Ibid; see discussion in: Christopher Garrison, 'Never say never - why the high income countries that opted-out from the Art 31bis WTO TRIPS system must urgently reconsider their decision in the face of the COVID-19 pandemic' (Medicines, Law and Policy, 8 April 2020). 
of extreme urgency', ${ }^{124}$ so that importation of health-technologies made under compulsory licence elsewhere can be used where needed by EU states within the COVID-19 context and other health emergency situations.

\section{CONCLUSION}

Given the devastating global impacts of the COVID-19 pandemic on human life, society and the broader economy, it is vital that affordable global access to vaccines, diagnostics and treatments for COVID-19 are available once these are developed, as such access must be delivered without delay. However, as has been demonstrated, patents, depending on how patent-holders choose to use them, can prove significant obstacles to such access. Accordingly, it is vital that national governments have effective mechanisms in place to temper patentholder control via compulsory licensing and government-use licences allowing states to intervene over patent-holder decision-making where needed. Such measures are also effective as negotiation tools for states, as often the threat of such licences will encourage patent-holders to offer access to patented health-technologies on more favourable terms.

Accordingly, the Irish government must re-evaluate the current framework for compulsory licensing and licensing for service of the state in Ireland to ensure the national legal framework applicable is as effective as possible, whilst remaining compliant with Ireland's international obligations. As demonstrated, shortcomings exist within the current framework in this context, and these should be addressed as soon as possible to offer a broader compulsory licensing system in Ireland which gives the state greater scope to intervene with patentholder's licensing decisions. More specifically, the following changes are needed:

1. legislative change to amend the grounds for compulsory licensing offered under section $70 \mathrm{PA}$;

2. legislative change to remove the three-year time restriction outside of the context of compulsory licensing for insufficient working of a patent;

3. offering further guidance at a national level on what is meant within the current grounds in relation to 'demand' in the state; and

4. offering national guidance and raising awareness of how 'adequate' remuneration will be determined with reference to overarching principles applicable. 
The article also proposes that the current provisions around licensing for service of the state are amended to incorporate:

1. legislative guidance making it clearer what threshold of supply or lack of supply is needed under section 78(a) and (b) PA;

2. legislative change removing the reference to 'exceptional circumstances' under section 78(2) and an express acknowledgment within the legislation that a pandemic/epidemic may constitute circumstances where licences for services of the state can be granted in the 'interests of the community' under this section; and

3. further guidance at a national level on the overarching principles used to determine adequate remuneration in such contexts.

Finally, obstacles to effective uses of such compulsory licensing mechanisms posed by EU data exclusivity and marketing exclusivity protections should be addressed as a matter of urgency, as these present significant practical impediments to using such licensing avenues for COVID-19 and for other public health crises. Ireland should petition the EU for a waiver to be provided within such protections where compulsory licences or licences for service of the state are issued. Ireland should also join calls for the removal of the EU's opt-out of the WTO framework allowing states to import medicines produced elsewhere under compulsory licensing.

In short, it is in all our interests, both in the health and economic sense, that COVID-19 is eradicated as soon as possible. It is also in all our interests that any obstacles to this eradication are addressed, and this includes obstacles created by patent rights. Compulsory licensing and licences for service of the state are an important tool to alleviate such access issues, which if left unchecked may significantly impede future access to supplies of medicines, vaccines and improved diagnostics for COVID-19. Allowing such potential patent obstructions to subsist without an effective avenue for remedy is contrary to all our interests, hence, using such licensing measures and adopting legislative provisions and national guidance to make the system for their use more effective within Ireland and other states is not only appropriate but wholly warranted. 